\title{
MULTINATIONAL LOGISTICS CADET EXERCISE FOURLOG
}

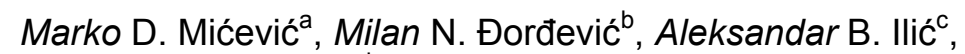
Nemanja N. Pavlović ${ }^{\mathrm{d}}$, Andrej J. Pinćir ${ }^{\mathrm{e}}$, Vlada S. Sokolovićf, Marjan A. Milenkov ${ }^{g}$

a University of Defence in Belgrade, Military Academy, Department for Military Mechanical Systems, Belgrade, Republic of Serbia, e-mail: markonilogistika@gmail.com, ORCID iD: 10 http://orcid.org/0000-0002-4562-2909

b University of Defence in Belgrade, Military Academy, Department for Military Mechanical Systems, Belgrade, Republic of Serbia, e-mail: milandjordjevicva@gmail.com, ORCID iD: 1 http://orcid.org/0000-0002-8054-3974

${ }^{\circ}$ University of Defence in Belgrade, Military Academy, Department for Military Electronic Systems, Belgrade, Republic of Serbia, e-mail: ackonislija@gmail.com, ORCID iD: Chttp://orcid.org/0000-0003-1291-4267

d University of Defence in Belgrade, Military Academy, Department for Logistics, Belgrade, Republic of Serbia, e-mail: berzerker996@gmail.com, ORCID iD: Dhttp://orcid.org/0000-0003-0708-7877

e University of Defence in Belgrade, Military Academy, Department for Logistics, Belgrade, Republic of Serbia, e-mail: a.pincir@gmail.com, ORCID iD: Dhttp://orcid.org/0000-0002-2634-2645

${ }^{f}$ University of Defence in Belgrade, Military Academy, Department for Logistics, Belgrade, Republic of Serbia, corresponding author, e-mail: vlada.sokolovic@va.mod.gov.rs, ORCID iD:

${ }^{9}$ University of Defence in Belgrade, Military Academy, Department for Logistics, Belgrade, Republic of Serbia, e-mail: marjan.milenkov@va.mod.gov.rs, ORCID iD: 1 http://orcid.org/0000-0003-2054-0525

DOI: 10.5937/vojtehg67-21983; https://doi.org/10.5937/vojtehg67-21983

FIELD: Military logistics, Training through simulations ARTICLE TYPE: Professional Paper ARTICLE LANGUAGE: English

\section{Abstract:}

In order to be prepared for the performance of functional duties after graduating from the Military Academy, military cadets participate in multinational cadet exercises. One of these exercises is the multinational logistics training exercise FOURLOG. This paper presents a brief description of the history of the mentioned cadet exercise, its organization and scenario as well as an overview of the tasks that cadets deal with in 
the roles of managing and executive logistics bodies. The experience gained during many years of participation of the cadets of the Military Academy, University of Defense in Belgrade at the above exercise is given as well.

Key words: exercise, logistics, training, education, international military cooperation, FOURLOG.

\section{Introduction}

Given the strategic commitment of the Republic of Serbia (RS) to the membership in the European Union (EU), it is clear that it is necessary to go towards more intensive security cooperation between the RS and the EU. Such cooperation contributes to the mutual interests of these entities, with the interest of the RS to create a basis for its own development and strengthening stability in the region and in the wider environment (Stojković, 2010).

Depending on the type and intensity of security challenges, risks and threats, among other things, the defense interests of the RS are protected by building a reliable partnership and by participating in multinational operations to build and preserve peace in the region and the world (Stefanović \& Forca, 2015). In line with the above, the members of Serbian Armed Forces are engaged in several missions under the mandate of the EU and the United Nations (UN). For this reason, the protection of the interests of the RS through international military cooperation requires adequate preparation of military cadets, future officers of the Serbian Armed Forces.

Improvement of the ability of future officers to work in the international environment as well as familiarization with the organization and technology of work in foreign armed forces are also achieved through the organization and realization of various joint exercises (Andrejić et al, 2017). International cadet exercises provide an opportunity to learn about foreign armaments and enable the assessment of applied knowledge and skills acquired during schooling. In doing so, they contribute to the improvement of linguistic skills, adoption of military terminology, and mastering of various procedures and team work, with the aim of training for the international scene (Persson, 2001).

When it comes to cadets, future officers, "exercises" involve the training of cadets since assignments are not realized independently, but through the supervision and leading of teachers (Venekei, 2008).

The aim of this paper is to present the origins and the development of the FOURLOG training exercise, its organization and scenario, as well 
as to give a review of the key tasks that cadets solve during the exercise in the roles of managing and executive logistics bodies.

\section{Concept of the FOURLOG exercise}

The multinational logistics cadet exercise FOURLOG has a tradition of almost two decades. The first exercise was realized in 2001, and the organizers of the exercise were the Defense University in Brno (Czech Republic) and the Budapest University of Public Administration (Hungary). A few years later, members of the Logistics School from Vienna (Austria) took part in the exercise. Since 2011, cadets of logistics of the Military Academy, University of Defense, Belgrade, have participated in the exercise (Venekei, 2015).

The cadet exercise FOURLOG was organized with the aim of preparing cadets, future logistics officers, for performing tasks in multinational operations (Pap \& Venekei, 2018), (Venekei, 2011). During the exercise, cadets receive various tasks that they deal with in the role of logistics team commanders and logistics management bodies in accordance with the specialties for which they are educated.

The problems that the cadets solve during the exercise are related to:

- the deployment and development of logistic units in the field,

- logistic support at specific positions and during movements of units,

- the work of logistics management bodies during the operation planing process (understanding and interpretation of positions and roles of both inividuals and logistic units during operations, logistic support (LS) in space and time, and LS organization through the functional areas of logistics),

- planning logistic support in the preparation of units for engagement in the zone of operation,

- scheduling logistic support during the operation execution,

- usage of software tools thoughout the LS planning process,

- understanding of the organization and operation of logistics elements during the operation.

The exercise was designed to cover a wide range of logistic problems in peacekeeping operations, and the realization of the exercise itself takes place in three different locations, through three phases:

- The preparation phase is implemented in Austria, and is aimed at familiarizing cadets with the generation of forces, the process of 
establishing a mission, the decision-making process and the use of logistics units during the operation;

- The LS planning and organization phase is implemented in Hungary, where planning and organization of logistic support is carried out;

- The logistic support implementation phase is implemented in the Czech Republic where cadets train the deployment of units, protection and movement of units in the city, and the implementation of LS. They also get acquainted with the place and role of the national support element.

According to the concept, the exercise lasts for two weeks. The exercise scenario is adapted to a peace support operation under the UN mandate, and the operation is carried out in an imaginary country in the territory of Central Europe with real geographical data.

According to the scenario, the UN made a decision to establish a UN mission in the imaginary state of EASTLAND which concluded the agreement between the conflicting parties on the termination of hostilities and the consent to deploy two UN divisions in their own territory. Based on a UN resolution, a decision was made to form corps called "EASTLAND FORCES - EFOR", where one of the brigades (ACHSPKBDE) is an imaginary unit in the exercise. The organizational structure of the unit is shown in Figure 1.

The task of the EFOR unit is the disarmament of paramilitary formations, ensuring the implementation of the cease of hostilities, securing peace negotiations, supporting internally displaced people, restoring infrastructure, preventing arms smuggling, and protecting the state borders of EASTLAND.

Based on the above scenario, cadets are divided into several groups where, through the roles of logistics managing and executive bodies, at the battalion level, they solve the tasks of planning, organizing and implementing logistic support. 


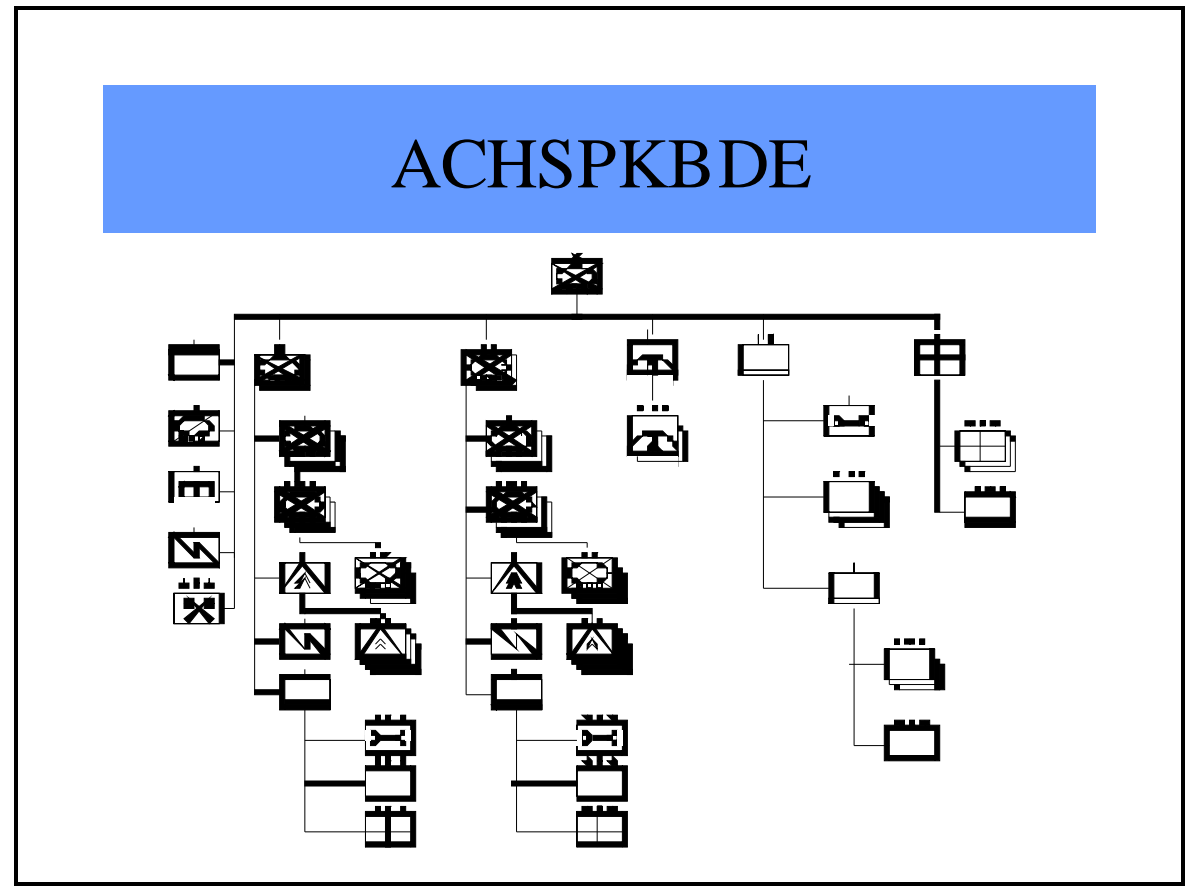

Figure 1 - Organizational structure of the brigade

Puc. 1 - Организационная структура бригады

Слика 1 - Организацијска структура бригаде

\section{Realization of the FOURLOG exercise}

As already mentioned, the exercise is realized in three phases. The first phase includes the preparatory part of the exercise, where cadets are introduced to the script, the situation in fictitious states and the UN decision on the establishment of the mission. The task of the cadets is to analyze and evaluate logistic support of the battalion, based on the available data, within the multinational brigade. Based on the analysis, the cadets prepare reports on the most important issues and risks that influence the execution of logistic support during the deployment phase of the forces and the execution of the operation.

The content of this part of the exercise is:

- an overview of the general and detailed situation on the ground,

- getting acquainted with the general and special tasks of the imaginary units,

- getting acquainted with the general and special tasks of LS, 
- mission analysis, with an emphasis on the factors that influence logistic support.

The goal for the cadets in this phase of the exercise is to understand the position and role of the logistics bodies and units in the upcoming operation, as well as the intentions of the superior command. Accordingly, it is necessary to determine the major activities until the establishment of the mission, to understand the assigned tasks and define the performed ones, and to develop a plan of activities of the logistics bodies and units until the task is completed. The mission analysis is carried out using a SWOT (Strengths, Weakness, Opportunities, Threats) analysis adapted to the needs of the logistics management staff at the tactical level.

In the plan of activities of logistics bodies, it is necessary for cadets to define the key LS activities and the critical times for the execution of the tasks, with all possible limitations. During the analysis, cadets take into account the limitations in space and time during the LS implementation in order to define more fully the main activities, assignments and tasks performed. The quantification of these constraints is done using the so-called 4D (Destination, Distance, Duration, Demand) analysis shown in Figure 2. This analysis requires from the cadets in the management role to determine the distribution of forces in the field, the supply lines between the supply zone and the zone of responsibility of the units, the duration of the activity from issuing an order to the deployment in the zone of responsibility, as well as activities within the zone of responsibility itself. Also, the analysis of cadets should also provide answers to the questions arising from the logistic requirements arising from the above activities. Cadets are given the opportunity to identify and define potential logistic requirements without any constraints and in accordance with the acquired knowledge, personal abilities and available time.

The definition of logistic requirements begins with the analysis of individual logistics functions, followed by the analysis of individual activities within the LS functions. Cadets calculate budget for supply needs by classes of supply, plan maintenance of materiel up to arriving in the zone of operation, transport organization, etc. An output document for the mission analysis is shown in Table 1. 


\section{Object and Factor Analysis (4D Analysis)}

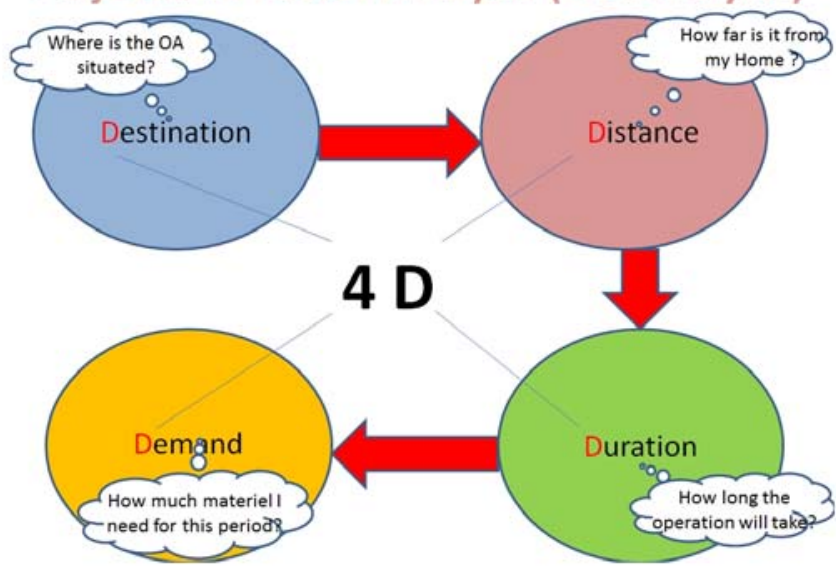

Figure 2 - Logistics 4D2 Analysis

Puc. 2 - Логистический 4Д2 анализ

Слика 2 - Логистичка 4Д2 анализа

Table 1 - Mission Analysis at the Tactical Level

Таблица 1 - Анализ миссии на тактическом уровне

Табела 1 - Анализа мисије на тактичком нивоу

INDIVIDUAL POSITION AND ROLE

THE AIM OF THE SUPERIOR COMMAND:

\begin{tabular}{|l|l}
\hline GIVEN TASKS & CRITICAL TIME/ACTIVITIES
\end{tabular}

\begin{tabular}{|l|l|l|}
\hline PERFORMED TASKS & CONSTRAINTS & NOTES
\end{tabular}

CRITICAL TASKS

FINAL STATE

During this phase of the exercise, cadets should recognize and define logistic requirements in a real and incompletely defined environment. Through such tasks, which have many unknowns, critical thinking is necessary in accordance with the principles of use of logistic 
capacities. In this way, each proposed solution is considered as a potential variant of the use of logistics resources; cadets, therefore, are not expected to have correct solutions, but to produce solutions in line with the principles of organization and operation of the logistics bodies and units.

A special activity at this stage of the exercise is the presentation of procedures for the deployment of elements of logistic support on the ground, performed by the professionals of the mechanized battalion of the Austrian army in Grosmitel. What is presented are the elements of the sections for fuel and ammunition supply, mobile machine shops for vehicle maintenance, procedures for recovering and evacuating combat vehicles (Figure 3 ) as well as the elements of the food and water sections.

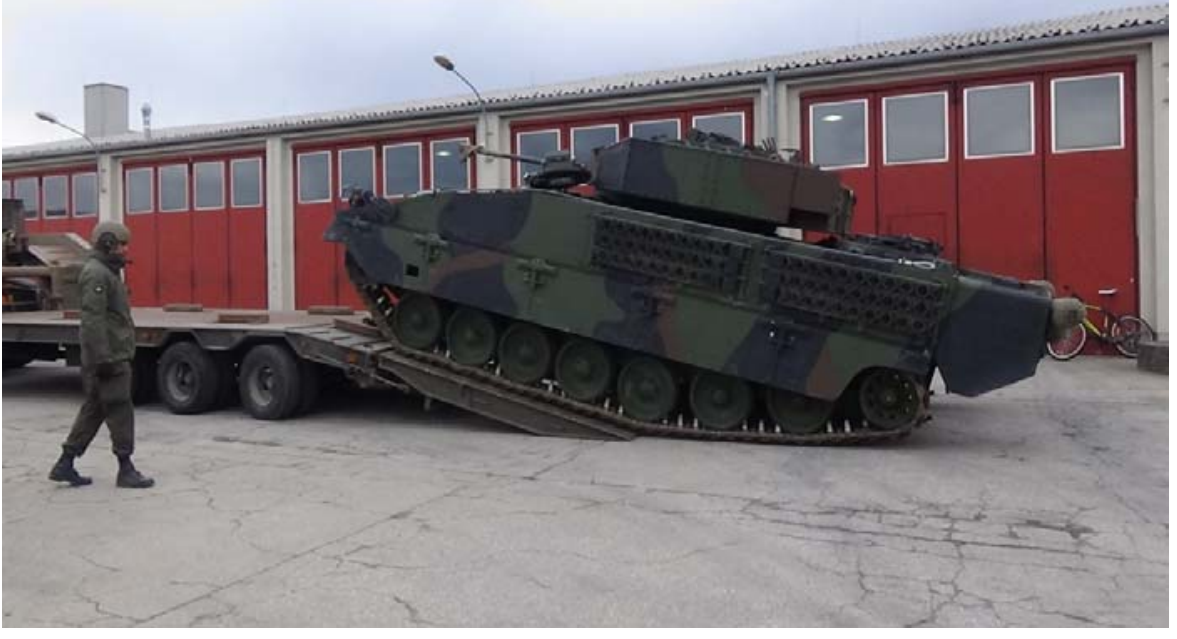

Figure 2 - Evacuation of a combat vehicle by a towing train

Puc. 3 - Эвакуация боевого транспортного средства буксирным составом Слика 3 - Евакуација борбеног возила вучним возом

In the second phase of the exercise, according to the scenario, the cadets form a working map, and with the help of the GeoMan software from the LOGFAS software package, show the spatial situation, Figure 4. In the GeoManager module, the structure of the forces is formed, the logistics capacities are defined, the infrastructure objects of importance for the execution of the operation are entered as well as all the key geographical parameters of space of importance for carrying out the 
upcoming operation. The module itself has a large number of tools for defining individual and group key elements such as object type, purpose, exact location, affiliation, capacity, etc.

The LOGFAS software package allows a detailed definition of the organizational structure and a formation of units regarding personnel and equipment, generated using a special module with a database of tactical, technical and logistic parameters of assets and formation elements of units, Logistics Data Management (LDM) , Figure 5.

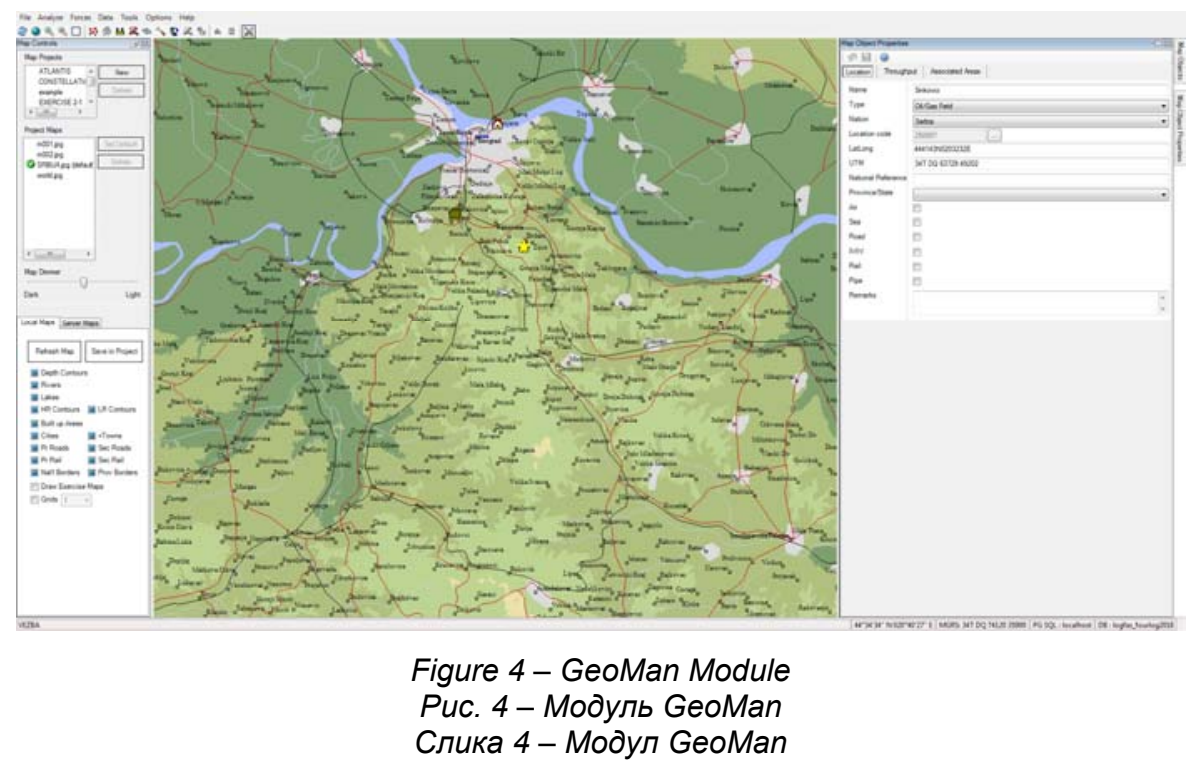

In the LDM module, the structure of a particular unit from the lowest to the highest level is formed. In this context, for each unit separately, based on the materiel formation, a list of all related assets (weapons, artillery, vehicles, equipment, etc.) is drawn up. Then, personnel and materiel are matched in order to gain complete insight into the personnel and materiel formation of units.

For the units thus formed, the software package offers various options such as: defining the route, scheduling transport at the tactical, operational and strategic levels, scheduling the supply by materiel classes, controlled distribution of information to different subjects, etc.

At this stage of the exercise, in addition to the above activities, cadets working in teams should also plan the transport of units within the operation zone. In addition, cadets develop plans to send units to the assigned zone of responsibility, (Figure 6), and calculate the required 
amount of material resources (fuel, food, water, etc.) for the task to be accomplished.

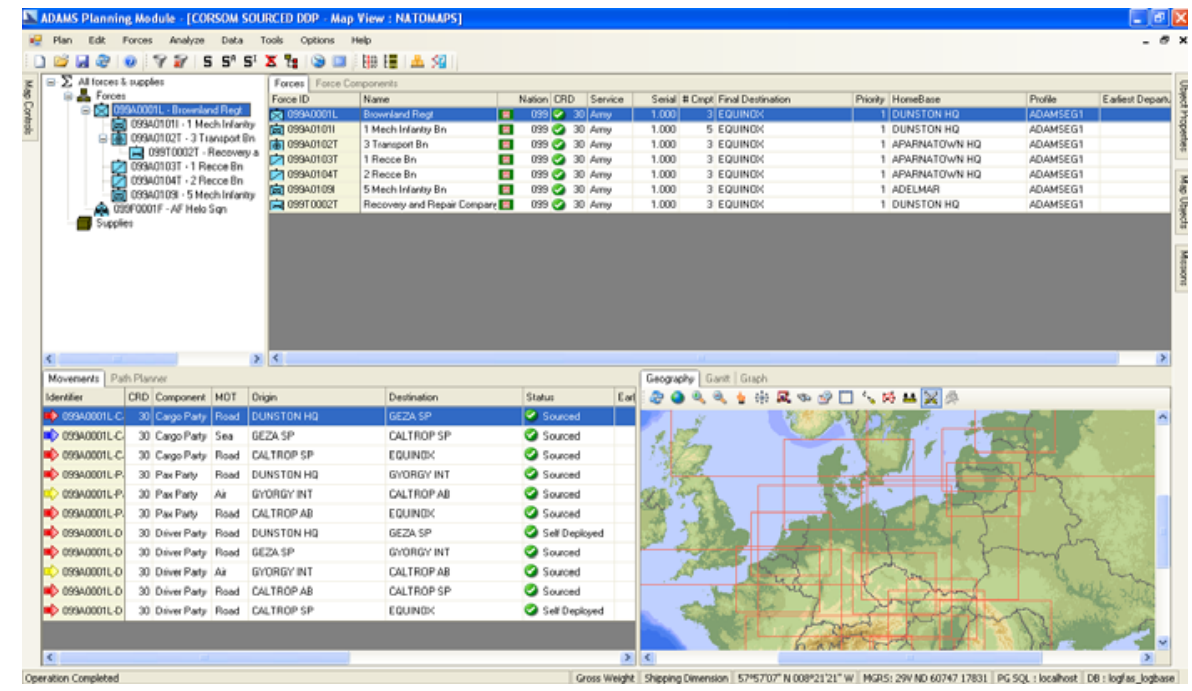

Figure 5-LDM software package

Puc. 5 - Пакет прикладных программ LDM

Слика 5 - Софотверски пакет LDM

COA SKETCH

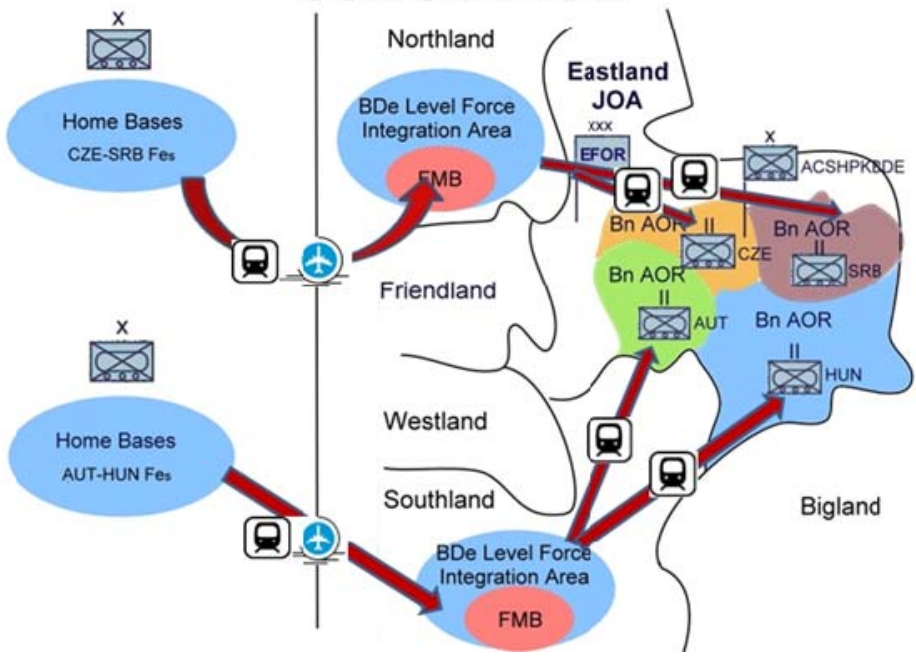

Figure 6 - Plan of sending units to the area of responsibility

Puc. 6 - План направления подразделений в зону ответственности Слика 6 - План упућивања јединица у зону одговорности 
According to the imaginary scenario, tasks in the field of supply, maintenance, transport and health are set in the opperation zone. One of the tasks is also logistics reconnaissance in order to get acquainted with the logistic capacities in the assigned zone of responsibility. The reconnaissance is conducted in coordination with representatives of local authorities who are prepared in advance by the teachers of the Budapest University of Public Service. Information collected during the reconnaissance is entered into the GeoManager module, passed to the superior command, and used in the logistic support planning process.

At this stage, cadets are also given the task of organizing emergency shelters and logistic support for internally displaced people. The task is to provide shelters, food and water supply, transport, health care, etc. Such a task imposes a need for cooperation with various structures in the mission, such as local authorities, civilian-military cooperation, police forces, etc. The problem posed this way allows cadets to gain insight into the complexity of logistic support of peacekeeping operations, as logistic requirements often come outside of the organizational structure and can be outside military frameworks. All this imposes a need for a more complex consideration of the issues of preparing personnel for participation in peacekeeping operations.

In the third phase of the exercises, cadets are given a supposed scenario in which the tactical situation has changed. The neighboring country BIGLAND has reorganized part of its forces - a mechanized battalion - on the northeastern border with EASTLAND. In response to such activities, the multinational command issued an order to reassign units in a possible direction of the attack from the territory of BIGLAND. Such a response from the multinational command aims at preventing a possible conflict, intrusion into the EASTLAND territory, and the prevention of combat support to the paramilitary forces of EASTLAND, as shown in Figure 7.

Cadets are assigned the task to plan and organize the transfer to the new zone of responsibility in the roles of the logistics authorities of the imaginary units. This task is realized through the following phases:

- Planning the movement, in accordance with realistic constraints and conditions on the ground;

- Calculation of the required amount of material resources (fuel, food, water, etc.) during the march;

- Determination of control points and formation of stations for fuel supply along the direction of movement of units;

- Commander's reconnaissance of the area of deployment of logistic units;

- Giving reports on the completed tasks. 


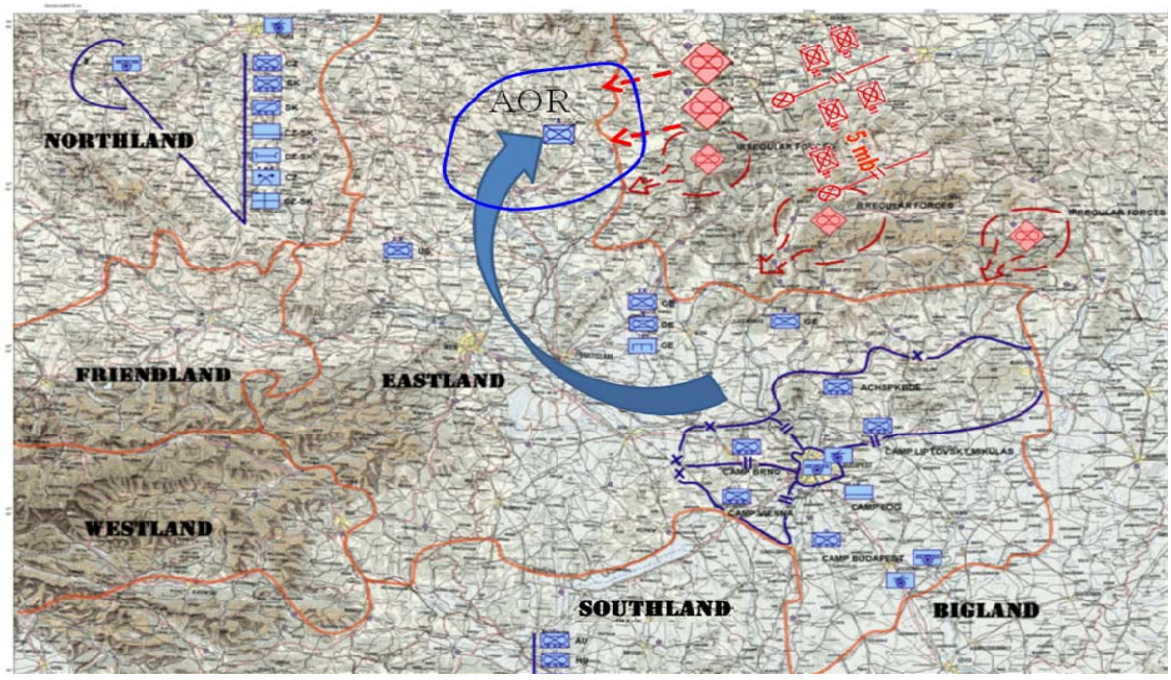

Figure 7 - Tactical situation at the beginning of the third phase of the exercise Puc. 7 - Тактическая обстановка в начале третьего этапа учений Слика 7 - Тактичка ситуација на почетку треће фразе вежбе

A special activity at this stage of the exercise is a practical training of cadets in the organization of fuel and ammunition supply stations, the organization of combat support of both stationary and moving logistical units, procedures for the evacuation of damaged and defective assets as well as the organization and technology of work in logistic units. A detail of cadets' activities in solving tasks of logistic support planning is shown in Figure 8.

A cadets' task is to set critical times (starting, stopping, reaching the destination), critical points along the direction of movement, supply points, and procedures in different situations during the march.

Depending on the assigned direction of movement and the characteristics of materiel from particular units, cadets calculate the required amount of fuel to supply the units on the move. Then, they determine suitable areas for the organization of fuel supply points along the direction of movement. In doing so, they must take care to ensure that refueling is carried out in such a way that there is no congestion and grouping of vehicles at these locations, primarily for security reasons. It is also necessary to predict the dynamics of fuel filling and consumption so that technical assets reach the destination with a fuel reserve for at least one day of combat by operating budget units (corresponding to a quantity of 0.2 tank filling). Based on the available and calculated parameters, cadets produce a march chart that they present during the referral. 


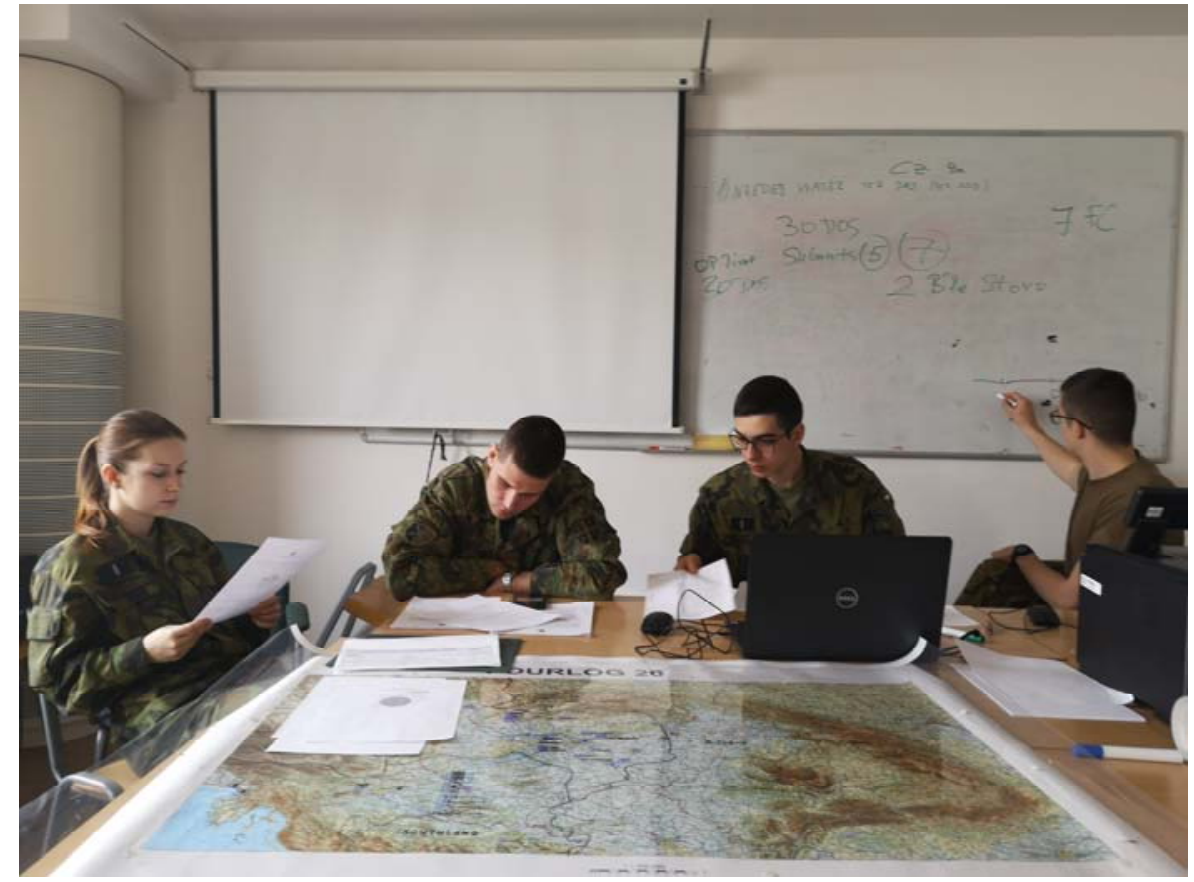

Figure 8 - The cadets' work on solving logistics support planning tasks Puc. 8 - Курсанты решают задачи по планированию логистической поддержки Слика 8 - Рад кадета на решавању задатака планирања логистичке подршке

Upon arrival in the next scheduled area, cadets in the role of logistics executive organs organize and implement command reconnaissance. Reconnaissance is carried out at several different locations in order to assess the situation on the ground for the needs of logistic units. Each cadet group is supervised by a certain number of teachers of the host country. After reconnaissance and a decision made on the logistic capacity allocations, cadets prepare their reports and present their own solutions to teachers.

\section{Experience from the previous exercises}

After analyzing the exercises in the period from 2012 to 2019 , the following conclusions can be drawn:

- During a two-week cadet training exercise, conditions are created for cadets to improve their communication skills in English language, especially in military and technical terminology. 
- During the exercises, the cadets had a wish to prove their worth and display the quality of the acquired knowledge during the education at the Military Academy. This was also noted during the evaluation of cadets' work by teachers and instructors from foreign countries, who especially emphasized the exceptional preparedness, motivation and capability of cadets of the Military Academy from the Republic of Serbia.

- Preparation of the Military Academy cadets for the participation in the exercise changed from year to year, in accordance with the acquired experience. In 2014, 60 hours of teacher and cadet work were planned, with 20 hours of individual work of cadets. From 2016, 20 hours of preparations with a teacher have been allocated together with 20 hours of independent work. The preparations include the introduction of cadets to peacekeeping operations, training for work in the LOGFAS software package, familiarization with the rules of engagement of units in peacekeeping operations, significance of cultural differences, as well as the technology of work of logistics staff and units in peacekeeping operations. Based on the previous exercises, it is concluded that this kind of cadet preparation has been established in an optimal way, since the cadets can easily engage in solving tasks during the exercise.

The collected materials from the previous exercises are included in the Logistics Course content in order to improve the logistics practice, as well as to prepare next generations of cadets for participation in the FOURLOG exercise.

\section{Conclusion}

Participation in the multinational logistics training program FOURLOG is useful for the Military Accademy cadets for their future duties after graduating.

This cadets' exercise allows them to learn more about the methods of cadet education in foreign higher military education institutions, about their cadets' knowledge, skills and abilities. The exercise is based on teamwork in an international environment where personal capabilities come to the fore in the field of the application of academic and practical knowledge acquired during schooling, as well as in the field of communication, especially in the readiness to take responsibility and leadership in an incompletely defined and uncertain environment.

The content of the exercise described is based on practical experience and the tasks are adapted to the cadets' level of knowledge and skills. Although the tasks represent segments of problems encountered by logistics authorities in international peacekeeping 
operations, they allow cadets to gain insight into logistics requirements with all positive and negative sides, which is one of the goals of the exercise itself.

Based on the past experience, it can be said that the participation of the Military Academy cadets in the FOURLOG exercise was commented positively, especially in terms of the cadets' motivation for work, desire to excel, applied knowledge and skills, and the use of software tools that are not otherwise used in domestic practice. Besides cadet training, this exercise helps in building up the reputation of the institution from which they come from and, consequently, the reputation of the Republic of Serbia, which is one of the ways of protecting the interests of the state through international military cooperation.

\section{References}

Andrejić, M., Milenkov, M., \& Sokolović, V. 2017. Školovanje logističkog kadra na evropskom putu Republike Srbije. Vojno delo, 69(1), pp.217-231 (in Serbian). Available at: https://doi.org/10.5937/vojdelo1701217A.

Pap, A., \& Venekei, J. 2018. The innovative elements of the conduct of fourlog logistics training 2018 and their application in military higher education. Hadmérnök, 13(2), pp.105-116.

Persson, S.G. 2001. Interoperability through Education, Training and Exercises-Simulations as a Means for Regional Cooperation with PfP Simulation Network as an Example. In: The 5th International Command and Control Research and Technology Symposium, Modeling and Simulation Track. Available at: http://dodccrp.org/events/5th_ICCRTS/papers/Track2/072.pdf [Accessed: 21 July 2019].

Stefanović, S., \& Forca, B. 2015. Preduslovi i neophodne mere za efikasno i efektivno učešće Vojske Srbije u misijama i operacijama zajedničke bezbednosne i odbrambene politike EU. Vojno delo, 67(3), pp.222-250 (in Serbian). Available at: https://doi.org/10.5937/vojdelo1503222s.

Stojković, B. 2010. Bezbednosni aspekti uključenja Republike Srbije u Evropsku Uniju. Vojno delo, 62(3), pp.166-189 (in Serbian).

Venekei, J. 2008. Experiences in the application of LOGFAS (Logistics Functional Area Services) in the Multinational Logistics Training Program Fourlog. AARMS - Academic and Applied Research in Military Science, 7(4), pp.607-616.

Venekei, J. 2011. Lessons learned from the execution of the Multinational Logistics Training Program FOURLOG 2011. Hadmérnök, 6(4), pp.276-281.

Venekei, J. 2015. A katonai logisztikai ellátási lánc koncepció fejlesztésének és alkalmazásának lehetőségei a Nemzeti Közszolgálati Egyetem alap- és mesterszakjainak multinacionális gyakorlati képzési programjaiban. Ph.D. thesis. Budapest: Nemzeti Közszolgálati Egyetem - Hadtudományi Doktori Iskola (in Hungarian). Available at: https://doi.org/10.17625/NKE.2015.018. 
МЕЖДУНАРОДНЫЕ КАДЕТСКИЕ ЛОГИСТИЧЕСКИЕ УЧЕНИЯ „FOURLOG“

Марко Д. Мичевича ${ }^{a}$ Милан Н. Джорджевич ${ }^{a}$,

Александар Б. Илич ${ }^{6}$, Неманя Н. Павловичв, Андрей Й. Пинчир ${ }^{\text {, }}$ Влада С. Соколович, корреспондент ${ }^{\text {, }}$ Марян А. Миленков ${ }^{\text {B }}$

а Университет обороны в г. Белград, Военная академия, Департамент военного механического инжиниринга, г. Белград, Республика Сербия

${ }^{\sigma}$ Университет обороны в г. Белград, Военная академия, Департамент военного электронного инжиниринга, г. Белград, Республика Сербия

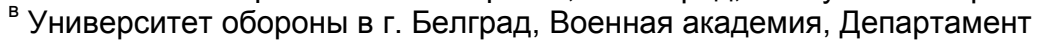
логистики, г. Белград, Республика Сербия

РУБРИКА ГРНТИ: 78.03.00 Учения о войне и армии

ВИД СТАТЬИ: профрессиональная работа

ЯЗЫК СТАТЬИ: английский

Резюме:

Одним из важнейших факторов подготовки курсантов к их будущей профрессиональной деятельности по завершении Военной академии является их участие в международных кадетских учениях. В данной работе представлена международная кадетская программа учений по логистике под названием „FOURLOG“. В статье также кратко описана история создания данных учений, организация, порядок проведения и сценарии, приведен обзор логистических задач, которые распределяются по ролям с учетом обязанностей управленческих и исполнительных членов логистического звена, а также описан опыт курсантов Военной академии, Университета обороны в Белграде, приобретенный в течение многолетнего участия в данных учениях.

Ключевые слова: учения, логистика, тренировка, образование, международное военное сотрудничество, FOURLOG.

МЕЂУНАРОДНА КАДЕТСКА ЛОГИСТИЧКА ВЕЖБА „FОURLOG”

Марко Д. Мићевић ${ }^{\mathrm{a}}$, Милан Н. Ђорђевић ${ }^{\mathrm{a}}$,

Александар Б. Илић ${ }^{6}$, Немања Н. Павловић ${ }^{\text {, }}$ Андреј Ј. Пинћир ${ }^{\text {, }}$

Влада С. Соколовић, аутор за преписку' ${ }^{\text {, Марјан А. Миленков }}{ }^{\text {в }}$

а Универзитет одбране у Београду, Војна академија, Катедра војномашинског инжењерства, Београд, Република Србија

${ }^{б}$ Универзитет одбране у Београду, Војна академија, Катедра војноелектронског инжењерства, Београд, Република Србија

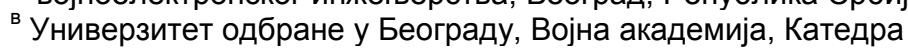
логистике, Београд, Република Србија

ОБЛАСТ: војна логистика, обука путем симулације ВРСТА ЧЛАНКА: стручни рад ЈЕЗИК ЧЛАНКА: енглескИ 


\section{Сажетак:}

Ради што боље припреме за обављање функционалних дужности након завршетка Војне академије кадети учествују на међународним кадетским вежбама. Једна од таквих је и међународна кадетска логистичка вежба „FOURLOG”. У раду је представљен кратак историјат ове кадетске вежбе, њена организација, сценарио и преглед задатака које кадети решавају у улогама управних и извриних органа логистике. Такође, наводе се и искуства стечена током вишегодишњег учешћа кадета Војне академије Универзитета одбране у Београду на овој вежби.

Кључне речи: вежба, логистика, обука, образовање, међународна војна сарадња, „FOURLOG”.

Paper received on / Дата получения работы / Датум пријема чланка: 02.06.2019.

Manuscript corrections submitted on / Дата получения исправленной версии работы / Датум достављања исправки рукописа: 19.08.2019.

Paper accepted for publishing on / Дата окончательного согласования работы / Датум коначног прихватања чланка за објављивање: 21.08.2019.

( 2019 The Authors. Published by Vojnotehnički glasnik / Military Technical Courier (www.vtg.mod.gov.rs, втг.мо.упр.срб). This article is an open access article distributed under the terms and conditions of the Creative Commons Attribution license (http://creativecommons.org/licenses/by/3.0/rs/).

() 2019 Авторы. Опубликовано в «Военно-технический вестник / Vojnotehnički glasnik / Military Technical Courier» (www.vtg.mod.gov.rs, втг.мо.упр.срб). Данная статья в открытом доступе и распространяется в соответствии с лицензией «Creative Commons» (http://creativecommons.org/licenses/by/3.0/rs/).

(c) 2019 Аутори. Објавио Војнотехнички гласник / Vojnotehnički glasnik / Military Technical Courier (www.vtg.mod.gov.rs, втг.мо.упр.срб). Ово је чланак отвореног приступа и дистрибуира се у складу са Creative Commons лиценцом (http://creativecommons.org/licenses/by/3.0/rs/). 